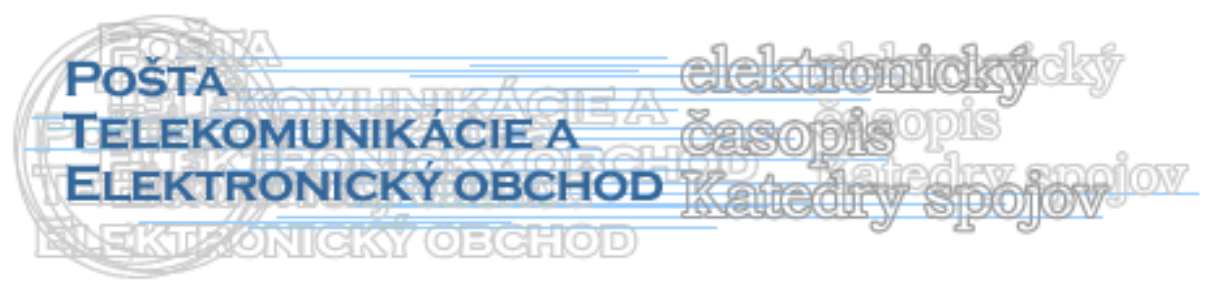

\title{
VYUŽITIE MARKETINGOVEJ KOMUNIKÁCIE PRI NAPĹŇANÍ ODBYTOVEJ STRATÉGIE PODNIKU
}

\author{
Viera Frianová ${ }^{1}$
}

\section{Úvod}

Odbyt považujeme za poslednú fázu podnikového procesu, ktorá ukončuje podnikový obeh hodnoty. Pri odbyte dochádza zhodnotením podnikových výkonov formou predaja vecných produktov alebo služieb k spätnému prílivu peňažných prostriedkov viazaných v podnikových procesoch, čo umožňuje realizáciu d'alšej a nepretržitej výroby.

Ciele, ktoré chce podnik na trhu dosiahnut' sú obsiahnuté v jeho odbytovej stratégii. Odbytová stratégia podniku sa realizuje za neustálej zmeny na trhu a úzko súvisí predovšetkým s výrobkovou stratégiou podniku. Určenie strategických ciel'ov v tejto oblasti by preto malo vychádzat' predovšetkým z výsledkov prieskumu potrieb na trhu, pričom okrem bežnej analýzy trhu a podnikovej situácie, je potrebné vytvorit' aj prognózu trhu (predbežný odhad budúcich daností trhu).

Ak považujeme marketing za určitú podnikatel'skú politiku (spôsob myslenia), koncepciu riadenia výroby a odbytu, ktorá vychádza z požiadaviek trhu a vyžaduje si prechod podnikovej ekonomiky z koncepcie výrobno-odbytovej na obchodno-výrobnú, možno konštatovat', že marketingová filozofia, ktorú podnik prijal, sa spredmetňuje aj vjeho odbytovej stratégii.

Teória a prax sa zhodujú v názore, že dosiahnutie ciel’ov stanovených v odbytovej stratégii je možné prostredníctvom využitia vhodných nástrojov, pričom za najdôležitejšie možno považovat' výrobkovú, kontraktačnú a v neposlednom rade aj komunikačnú politiku podniku.

\section{Marketingová komunikácia a odbytová stratégia podniku}

Úvodom tejto časti je potrebné zdôraznit', že pre oblast' marketingu sú platné všetky všeobecné poznatky o komunikácii, pričom komunikáciu v marketingu je možné chápat' dvojako. V prípade širšieho chápania (komunikácia pôsobí smerom od spotrebitela k výrobcovi či predajcovi), marketingová komunikácia zahŕňa všetky aktivity počnúc marketingovým výskumom cez vývoj a výrobu, cenotvorbu až po samotný predaj produktov a zabezpečuje tak plnenie základného poslania marketingu - poznat' trh, jeho potreby a na základe toho ponúknut' optimálny spôsob ich uspokojenia. V prípade užšieho chápania (komunikácia pôsobí od výrobcu k spotrebitel'ovi či sprostredkovatel'ovi) možno marketingovú komunikáciu chápat' ako jeden $\mathrm{z}$ nástrojov marketingu (ako jedno z vymedzených $\mathrm{P}$ - promotion) (Grančičová, 1999).

\footnotetext{
${ }^{1}$ Ing. Viera Frianová, Katedra manažmentu, Akadémia Ozbrojených síl gen. M. R. Štefánika, Liptovský Mikuláš tel. 0960423525

e-mail: frianova@aoslm.sk
} 
Komunikácia je považovaná za nástroj, ktorý predovšetkým umožňuje preklenút' problém oddelenosti výrobcov a trhu. Komunikáciu so zákazníkom potom možno definovat' ako ciel'avedomú činnost' zameranú na vyvolanie a usmernenie potrieb, ktoré sa uspokojujú prostredníctvom kúpy produktu firmy. Úlohy komunikácie, ktoré možno odvodit' od marketingových ciel’ov firmy, majú ekonomický i mimoekonomický charakter. Môžeme ich rozdelit' na úlohy vo vzt’ahu k zákazníkovi a na úlohy vo vzt’ahu k firme. Vo vzt’ahu k zákazníkovi ide predovšetkým o poskytovanie informácií spojených s kúpou a využívaním produktu; komunikácia napomáha pri vytváraní predstavy o produkte (najmä voblasti služieb), ovplyvňuje a vychováva zákazníkov k využívaniu produktu a pod. Vo vzt'ahu $\mathrm{k}$ firme ide o napomáhanie pri rovnomernom využívaní kapacít, informovanosti o nových, málo známych alebo neznámych produktoch a pod. (Királ'ová, 1992). Netreba však zabúdat' na to, že podniky nekomunikujú len so svojimi zákazníkmi, ale aj so sprostredkovatel'mi a širokou verejnost'ou. „Ciel'om komunikácie tak môže byt' snaha dosiahnut' skutočnú a trvalú zmenu postojov, názorov a konania najrozličnejších ciel'ových skupín, čo si vyžaduje poznanie publika, okolností komunikácie, dobrú stratégiu, jej realizáciu a primerané vyhodnotenie, prípadne korekcie, t. j. realizáciu strategického komunikačného procesu“ (Žáry, 2001).

Marketingová filozofia, ktorú podnik prijal, sa spredmetňuje aj v jeho stratégii predaja resp. širšie v jeho odbytovej stratégii (Sedlák, 2002). Východiskom pre tvorbu odbytovej stratégie podniku musia byt' poznatky o celkovej stratégii podniku, resp. poznatky o tzv. podnikových ciel'och, ked’že základom každej stratégie je formulovanie ciel'ov a ciele odbytu resp. predaja musia vychádzat' $\mathrm{z}$ celkových podnikových ciel'ov. Teória a prax odbytovej stratégie hovoria, že vždy treba vychádzat' $\mathrm{z}$ viacerých nástrojov (prvkov) tejto stratégie. Uvedená nutnost' vedie k tomu, že sa odbyt/ predaj vysvetl'uje ako kombinovaný proces využitia nástrojov odbytovej stratégie resp. stratégie predaja. Vychádzame pritom z poznania, že jednotlivé nástroje tejto stratégie svojou povahou a intenzitou uplatnenia pôsobia diferencovane nielen na výšku nákladov, ale aj na samotný predaj. Potom môžeme v kombinácii nástrojov postupovat' tak, že hl’adáme optimálnu kombináciu pre zabezpečenie určitej požadovanej úrovne predaja (pričom rozhodujúcim kritériom optimalizácie môže byt' nákladová stránka uplatnenia nástrojov predaja) alebo kombinujeme nástroje stratégie predaja s ciel'om maximalizácie predaja (pričom prvoradým kritériom je maximalizácia tržieb a aspoň ako doplňujúce kritérium sa väčšinou sleduje aj nákladová stránka použitia nástrojov predaja) (Kupkovič, 2002). Podstata stratégie predaja ako jednej z funkčných stratégií podniku potom spočíva $\mathrm{v}$ tom, že vykonáva funkciu nástroja vo vzt’ahu k realizácii základnej stratégie podniku a jeho podnikatel'ských (obchodných) stratégií. Z čoho vyplýva potreba jej zladenia s ostatnými funkčnými (nástrojovými) stratégiami podniku, t. j. finančnou, zásobovacou, investičnou, výrobnou a pod. (Majtán, 2002).

Odbytovú stratégiu podniku možno považovat' za východisko pre tvorbu a realizáciu jeho odbytovej politiky, teda za východisko uplatňovania konkrétnych nástrojov marketingového mixu v krátkom časovom horizonte. Podl'a Tietza sa v rámci realizácie odbytovej stratégie využívajú: nástroje tovaru a služieb (tvorba produktu, sortimentná a produkčná línia), peňažné nástroje (finančné a garančné podmienky), informačné a komunikačné nástroje (reklama, intenzita kontaktov a prezentácie), inštitucionálne orientované nástroje a odbytové cesty, vedl’ajšie nástroje (služby zákazníkom). Meffert v súvislosti so systematizáciou jednotlivé nástroje zoskupil a následne ich prezentuje ako tzv. výrobkový resp. produkčný mix, distribučný mix, kontraktačný mix a komunikačný mix. Niektorý autori v snahe aplikovat' nástroje univerzálnejšie (pre viaceré podniky), zužujú ich vymedzenie len na politiku cenovú a konkurenciu v oblasti kvality. Uvedené členenie sa javí ako účelné, ked'že poukazuje na skutočnost', že odbytová politika sa presadzuje bud' cenou, vrátane politiky množstva alebo kvalitou. Cena vystupuje ako kritérium, z ktorého sa 
vychádza, kvalita sa v širokom ponímaní vzt'ahuje nielen na tovar, ale aj na podnik (služby zákazníkom, sortiment, reklama), čo vyvoláva u zákazníkov preferencie (Longauerová, 1992).

Wőhe $\mathrm{v}$ rámci členenia nástrojov stratégie predaja rozlišuje: cenovú politiku (aktívna cenová politika a politika množstva) a preferenčnú politiku (reklama, tvorba výrobku a sortimentu, služby zákazníkom, metódy odbytu) (Kupkovič, 2002).

Napriek prezentovanému množstvu názorových postojov ku problematike nástrojov odbytovej stratégie možno záverom konštatovat', že teória a prax sa v konečnom dôsledku zhodujú v názore, že za najdôležitejšie nástroje tejto stratégie možno považovat': kontraktačnú politiku, výrobkovú politiku a komunikačnú politiku.

\section{2 Komunikačná politika podniku}

Existuje niekol'ko spôsobov, ako poslat' komunikačný oznam vybranému segmentu trhu. Királ'ová, A. (1992) uvádza, že medzi najvýznamnejšie spôsoby patria: podpora predaja, nepriama komunikácia zahŕňajúca najmä reklamu, public relations a osobný predaj. Využívanie vybraných nástrojov komunikácie s ciel'om dosiahnut' podnikom stanovené ciele môžeme súhrnne označit' pojmom komunikačná politika podniku. Majtán, Š. pod uvedeným pojmom rozumie predovšetkým reklamu a d'alšie formy podpory predaja a styku s verejnost'ou.

V najnovšej literatúre sa môžeme stretnút' s dvomi významnými fenoménmi ovplyvňujúcimi tvorbu komunikačnej politiky podniku. Hovorí sa o presadzovaní tzv. ekologickej komunikačnej politiky a v súvislosti s novými paradigmami marketingu v procese globalizácie trhov sa zdôrazňuje potreba štandardizácie v komunikačnej politike.

Úlohou ekologickej komunikačnej politiky je vytvorit' predpoklad pre úspech ekologickej politiky odbytu tým, že ciel'avedome pôsobí na správanie partnerov v procese predaja. Dôležitost' sa pritom pripisuje pozitívnemu imidžu podniku a výrobkov u odberatel'ov v súvislosti so životným prostredím. Imidž výrobku sa prenáša na kupujúceho tak, že sa podporuje jeho osobná snaha chránit’ životné prostredie. V praxi sa osvedčujú nielen nové opatrenia zamerané špeciálne na ochranu životného prostredia ale aj nástroje ekologickej komunikačnej politiky pri práci s verejnost’ou (Kurtiš, 2001).

Štandardizácia v komunikačnej politike sa týka medzinárodného zjednotenia komunikačných nástrojov, ktoré sú nástrojom ovplyvňovania kupujúcich. V popredí úvah o štandardizácii stojí klasická reklama, podpora predaja a public relations (Čihovská - Kita, 2005)

\section{Komunikácia ako jeden $\mathrm{z}$ nástrojov marketingového mixu}

V literatúre sa v súvislosti s optimalizáciou kombinácie nástrojov odbytovej stratégie stretávame s pojmom marketingové nástroje (marketingový mix). Optimálna kombinácia uvedených nástrojov by mala zohl'adňovat' jednak stránku kvalitatívnu (výber vhodných nástrojov, ktoré budú použité) ako aj stránku kvantitatívnu (prisúdenie dôležitosti - váhy jednotlivým vybraným nástrojom) (Majtán, 2002).

$\mathrm{Za}$ jeden $\mathrm{z}$ najviditel'nejších a najdiskutovanejších nástrojov marketingového mixu, ktorý významne podmieňuje úspešnost' riadenia firmy, je považovaná práve komunikácia. Klasická koncepcia marketingu založená na marketingovom mixe známom ako tzv. štyri P: produkt (Product), cena (Price), miesto (Place) a propagácia (Promotion), sa stále častejšie stáva predmetom kritiky práve preto, že na trh pozerá predovšetkým z pohladu predávajúceho, a zanedbáva tak hl'adisko kupujúceho (zákazníka). Zatial' čo sa pracovníci marketingu na seba pozerajú ako na l'udí predávajúcich určitý produkt, zákazníci sa považujú za l'udí kupujúcich hodnotu alebo hl'adajúcich riešenie nejakého problému. Teda ak kupujúci zvažuje nejakú ponuku, nemusí ju vidiet' očami predávajúceho. Vychádzajúc z tohto prístupu, možno následne každé $\mathrm{z}$ vyššie uvedených tradičných $\mathrm{P}$ marketingového mixu, označit' z pohl'adu kupujúceho ako jedno zo štyroch $\mathrm{C}$ : produkt by mal $\mathrm{z}$ pohl'adu zákazníka 
reprezentovat' určitú hodnotu (Customer Value); viac ako cena zaujímajú zákazníka celkové náklady, ktoré musí vynaložit' na to, aby produkt získal a mohol ho používat' (Cost to the Customer); miesto distribúcie produktu by malo byt' pre zákazník dostatočne pohodlné (Convience); a napokon propagácia by mala byt' z pohl'adu zákazníka nahradená práve dvojstrannou komunikáciou (Communication). Foster, T. R. V. (2002) zdôrazňuje, že schopnost' uspokojit' zákazníkov významne súvisí so spôsobom, ako s nimi komunikujeme. „Spokojní zákazníci sú tí, ktorí sú informovaní. Chcú vediet', čo sa deje, chcú vediet' o zmenách (či už pozitívnych alebo negatívnych), ktoré budú mat' na nich vplyv a chcú sa o nich dozvediet' včas od vás, nie z televíznych správ“".

Úlohy komunikácie s adresátom (napr. zákazníkom) možno názorne prezentovat' prostredníctvom modelu AIDA. AIDA sú začiatočné písmená anglických termínov označujúcich reakcie ciel'ového publika $\mathrm{v}$ závislosti od jednotlivých fáz komunikačného procesu. Aby sa správa a v nej obsiahnuté posolstvo prepracovali k mysliam a dušiam adresátov, je potrebné prekonat' niekol'ko stupňov: získat' si Attention (pozornost') ciel'ového publika, podnietit' a udržat' Interest (záujem) o obsah správy, vzbudit' Desire (túžbu, želanie) a vybudovat' zámer konat' $\mathrm{v}$ duchu posolstva a napokon dosiahnut' Action (konanie) tých, ktorí sa správajú v zhode s posolstvom. Pôsobenie uvedeného modelu možno popísat' na príklade správania sa spotrebitel'a: získavanie pozornosti spotrebitel'a je nevyhnutné preto, aby si uvedomil existenciu určitej ponuky na trhu, vzbudenie a udržanie jeho pozornosti dáva šancu na zvýšenie jeho záujmu o produkt, vzbudenie želania ovplyvňuje proces spotrebitel'ovho hodnotenia a možno aj vytvorenia jeho preferencií, dosiahnutie konania či akcie znamená chut' spotrebitel'a získat' daný produkt, čo pravdepodobne povedie k jeho kúpe (Ďad'o, 1992).

V súlade s uvedeným môžeme vyčlenit’ nasledovné fázy komunikačného procesu:

- fázu oznámenia,

- fázu vyvolania záujmu,

- fázu pozitívneho naladenia vo vzt’ahu k predmetu komunikačného oznamu,

- fázu aktivizácie činnosti.

Počas fázy oznámenia firma sprostredkúva informácie vybranému segmentu trhu o svojom pôsobení na trhu a šírke ponuky. Vo fáze vyvolania záujmu možno predpokladat', že potenciálni zákazníci už poznajú základné informácie o firme a jej ponuke. V tejto fáze očakávajú d'alšie informácie, ktoré zlepšia a rozšíria informovanost' ohl'adom užívatel'ských výhod a predností, ktoré zákazníci získajú kúpou produktu firmy. Komunikačný oznam zameraný na vyvolanie záujmu často obsahuje iracionálne a emocionálne prvky, ktoré vyvolávajú v každom prijímatel'ovi oznamu subjektívne reakcie. Oznam tak ponecháva priestor pre širokú škálu individuálnych interpretácií a reakcií. Fáza pozitívneho naladenia zákazníka k predmetu komunikačného oznamu má za ciel' vyvolat' u potenciálneho zákazníka pozitívnu predstavu (image) o produkte alebo firme, ktorá produkt ponúka a želanie produkt vyskúšat' a kúpit'. Aktivizácia činnosti je konečnou fázou komunikačného procesu, ide o aktivizáciu akéhokol’vek konania prijímatel’a komunikačného oznamu, ktoré vyústi do kúpy produktu (okamžite alebo v budúcnosti) (Frianová, 2000).

\section{Stratégia komunikačného/propagačného mixu}

Clemente, N. M. (2004) označuje aktivity využívané na prenos informácie o výrobku, ktorý má byt' predstavený pre spojenie s potenciálnymi zákazníkmi a s ostatnou verejnost'ou ako marketingový komunikačný mix (marketing communications mix). Autor d’alej uvádza, že marketingové komunikačné mixy pozostávajú zo štyroch hlavných nástrojov: reklamy, podpory predaja, public relations a osobného predaja. Všeobecné rozhodnutie o marketingovej komunikácii zahŕňa rozhodovanie o tom, čo povedat', komu to povedat' a ako to povedat'. Tieto rozhodnutia obsahujú tzv. komunikačnú stratégiu spoločnosti. Vývoj tejto 
stratégie zahŕňa zistenie ciel’a poslucháčov, divákov, čitatel'ov atd'. a ich charakteristík, stanovenie komunikačných ciel'ov (napr. pripravenie spotrebitel'a na to, aby si produkt uvedomoval, aby sa mu páčil, alebo si vytvoril pre daný produkt preferencie), rozhodnutia o komunikačných kanáloch, stanovenie rozpočtu na komunikáciu a rozhodovanie o tom, ako monitorovat' účinnost' komunikácie a spätnú väzbu so spotrebitel'om.

Podla Š́bla, D. (2002) možno komunikačný mix (communication mix) definovat' ako: „súhrn prvkov komunikácie firmy s okolím a spôsob ich kombinácie. Jeho súčast'ou sú najmä reklama, podpora predaja, osobný predaj, vzt'ahy s verejnost'ou, vel'trhy a výstavy. Prvky marketingu sa pri vytváraní komunikačnej stratégie kombinujú, a to podla skúseností, znalostí a zodpovednosti manažmentu firiem. Tento proces l'ahšie prebieha v prostredí domáceho trhu, pri jeho aplikácii v prostredí medzinárodných trhov treba brat' do úvahy rôzne bariéry, napr. kultúrnu bariéru jednotlivých trhov, bariéru rôznych miest vzniku posolstva a jeho použitia a pod.“

Propagačným mixom (promotion mix) Clemente, N. M. (2004) rozumie kombináciu propagačných (promočných) techník používaných na komunikáciu informácií o produkte alebo službe smerom k ciel'ovému trhu. Propagačný mix na delí do dvoch kategórií na: priamu propagáciu (direct promotion) - zahŕňa osobný predaj spotrebitel'om (bud' z očí do očí alebo vd'aka technikám ako je telemarketing), nepriamu propagáciu (indirect promotion) obsahuje použitie reklamy, publicity a propagácie predaja t. j. taktiky komunikácie informácie o produkte prostredníctvom neosobných kanálov.

Tvorba stratégie propagačného mixu je založená na identifikácii ciel'ového trhu, na ktorý má byt' nasmerovaná komunikácia a stanovení ciel’ov komunikácie (napr. rozhodnutie, aké informácie je potrebné poskytnút', ako sú určené a ako sa menia úrovne spotrebitel'ského povedomia a postoje o produkte). V rámci propagácie sa rozlišuje: propagácia imidž (image advertising), propagácia medzi spotrebitel'mi (consumer promotion), propagácia na predajnom mieste - P-O-P (point-of-purchase advertising), propagácia obnovenia predplatného (renewal promotion), propagácia pomocou adresára (directory advertising), propagácia pre získanie člena členom (member-get-member promotion), propagácia pred tlačou (pre-print advertisement), propagácia verejných služieb (public service advertising), propagačné materiály (collateral materiale), propagačné oceňovanie - tvorba cien (promotion pricing), propagačné skonto - odmena (promotional allowance).

Stratégia propagačného mixu, ktorú si firma vyberie pre komunikáciu s daným segmentom trhu závisí predovšetkým od povahy produktu a štádia jeho životného cyklu, ciel'a propagácie, identifikácie ciel'ového trhu, na ktorý má byt' komunikácia nasmerovaná, charakteru konkurencie a rozpočtu na propagáciu. Je potrebné zdôraznit', že za dôležitú súčast' propagačnej činnosti je potrebné považovat' aj samotných pracovníkov predaja, ktorí úzko spolupracujú so sprostredkovatel'mi nielen preto, aby získali objednávky, ale tiež aby vysvetl'ovali marketingový mix svojej firmy a nadviazali spoluprácu s jednotlivými predajňami a koordinovali tak úsilie medzi jednotlivými článkami distribučnej cesty. Hlavnou úlohou marketingového manažéra v oblasti propagácie je informovat' ciel’ových zákazníkov o tom, že správny produkt možno získat' (kúpit') na správnom mieste a za správnu cenu. Aké informácie marketingový manažér poskytuje závisí od potrieb a názorov cielových trhov. Ako sú tieto správy podávané, záleží na tom, aké spojenie rôznych metód propagácie marketingový manažér vyberie (McCarthy, 1995).

Dlhodobá stratégia firmy je založená na tvorbe a posilňovaní obrazu značky na verejnosti, posilňovaní vernosti užívatel'a i na tom, že firma získava nových užívatel'ov. Obraz spoločnosti na verejnosti je stredobodom akejkol'vek strategickej dlhodobej komunikácie firmy (Smith, 2000). 


\section{Záver}

Odbor marketingovej komunikácie prešiel na prelome storočí celou radou zmien. Osvedčené schémy prestávajú platit'. Stotožňovanie komunikácie s televíznymi spotmi je už dávno minulostou. Komunikácia je stále selektívnejšia a spotrebitel' tiež stále vyberavejší, imúnny $\mathrm{k}$ doposial' účinným formám. Tam, kde doposial postačovala reklama vo svojom štandardnom poňatí, nastupuje komunikačný projekt, ktorý využíva mnoho nových netradičných nástrojov (Frey, 2005). Marketingová komunikácia sa v súčasnosti stáva stále viac previazanejšia s ostatnými zložkami marketingu $\mathrm{v}$ dôsledku možnosti rýchle analyzovat' údaje o predaji a vd’aka lepšej meratel'nosti účinkov komunikácie. To vedie k dosahovaniu vyššej efektívnosti všetkých marketingových nástrojov. Schopnost' rýchlej interakcie s distribučnými ret’azcami a s cenovou politikou ovplyvňuje inovácie a zmeny produktu, a to ovel'a rýchlejšie ako v minulosti. Nové trendy v marketingovej komunikácii tak postupne menia celkový prístup a myslenie marketingových pracovníkov.

\section{Literatúra}

1. CLEMENTE, N. M.: Slovník marketingu. Brno: Computer Press, 2004, ISBN 80-2510228-9

2. ČIHOVSKÁ, V. - KITA, J.: Nové paradigmy marketingu v procese globalizácie trhov. Ekonomický časopis. č. 6/2005, ISSN 0013-3035

3. ĎAĎO, J. - KIRÁl'OVÁ, A. - LESÁKOVÁ, L.: Marketing v drobnom podnikaní. Bratislava: EU Bratislava, 1992, ISBN 80-225-0420-3

4. FORET, M.: Marketingová komunikace. Brno: Computer Press, 2003, ISBN 80-7226$811-2$

5. FREY, P.: Marketingová komunikace. Praha: Management Press, 2005, ISBN 80-7261129-1

6. HURSTOVÁ, B.: Encyklopedie komunikačních technik. Praha: Grada Publishing, 1994, ISBN 80-85424-40-1

7. IŽARIK, Š. - FRIANOVÁ, V. a kol.: Základy marketingu. Liptovský Mikuláš: Vojenská akadémia, 2000, ISBN 80-8040-146-2

8. KOTLER, P.: Marketing od A do Z. Praha: Management Press, 2003, ISBN 80-7261-0821

9. KOTLER, P.: Marketing podle Kotlera. Praha: Management Press, 2004, ISBN 80-7261010-4

10. KUPKOVIČ, M. a kol.: Podnikové hospodárstvo. Bratislava: Sprint vfra, 2002, ISBN 8088848-93-8

11. KURTIŠ, P.: Základné optimalizačné metódy v enviromentálne orientovanej logistike. Bratislava: STU v Bratislave, 2001

12. MAJTÁN, Š. a kol.: Odbytová stratégia. Bratislava: Ekonóm, 1999, ISBN 80-225-1082-3

13. MARKOVÁ, V. - LONGAUEROVÁ, A. - ŠULAJOVÁ, I.: Podnikovohospodárska náuka. Bratislava: Edičné stredisko Vysoká škola ekonomická v Bratislave, 1992, ISBN 80-225-0381-9

14. MCCARTHY, J. E. - PERREAULT, W. D.: Basic marketing. Boston: IRWIN, 1990, ISBN 0-256-06865-8

15. MCCARTHY, J. E. - PERREAULT, W. D.: Základy marketingu. Praha: Victoria Publishing, 1995, ISBN 80-85605-29-5

16. PELSMACKER, P. - GEUENS, M. - BERGH, J.: Marketingová komunikace. Praha: Grada Publishing, 2003, ISBN 80-247-0254-1

17. SEDLÁK, M. a kol.: Podnikové hospodárstvo. Bratislava: Alfa, 1992, ISBN 80-0501108-3 
18. SMITH, P.: Moderní marketing. Praha: Computer Press, 2000, ISBN 80-7226-252-1

19. ŠÍBL, D.: Vel'ká ekonomická encyklopédia. Bratislava: Sprint, 2002, ISBN 80-89085-040

20. ŽÁRY, I.: Public relations - komunikačná disciplína. Otázky žurnalistiky, č. 1-2/2001, ISSN 0322-7049 